\section{Platelet Membrane Glycoprotein Illa Contains Target Antigens that Bind Anti-Platelet Antibodies in Immune Thrombocytopenias}

Diana S. Beardsley, Judith E. Spiegel, Michael M. Jacobs, Robert I. Handin, and Samuel E. Lux IV Division of Hematology-Oncology, Children's Hospital and DanaFarber Cancer Institute, and Brigham \& Women's Hospital, and Departments of Pediatrics and Medicine, Harvard Medical School, Boston, Massachusetts 02115

thrombasthenic platelets. Target antigens were localized to glycoprotein IIIa, but are different from $\mathrm{Pl}^{\mathrm{Al}}$. The immune thrombocytopenic purpura antigenic system is clearly distinguished from nonspecific platelet-associated IgG. Sera from eight children with acute idiopathic thrombocytopenic purpura were also studied. In all cases, the nonspecific IgG binding to the 200,000 -mol wt protein was observed. However, we were unable to demonstrate antibody binding to glycoprotein IIIa, which suggested that the acute childhood form of this disease may have a different pathogenic mechanism than that of the autoimmune chronic cases.

\section{Introduction}

Antibody mediated platelet destruction is a common cause of thrombocytopenia and clinical bleeding (1-3); however, the precise mechanism of platelet destruction is not known. More than $30 \mathrm{yr}$ ago Harrington et al. (4) reported that the globulin fraction of plasma from patients with immune thrombocytopenic purpura (ITP) ${ }^{1}$ contained a factor responsible for platelet destruction. Possible agents for such opsonization of platelets might include true autoantibodies, immune complexes, and antibodies crossreactive with viral and platelet antigens.

While an increased amount of immunoglobulin is often found associated with platelets in these syndromes (5-8), its role in platelet destruction is unclear. Recently, the significance of the increase in platelet-associated IgG (PAIgG) found in immune-mediated platelet destruction has been questioned $(9$, 10). There is great variation in levels of PAIgG among patients with ITP, but poor correlation between PAIgG levels and clinical course of the disease $(1,2)$. Current techniques for

1. Abbreviations used in this paper: BSA/BGG, 10\% (wt/vol) BSA, $0.5 \%$ bovine gamma globulin in PBS; GPIIla, glycoprotein IIIa; ITP, immune thrombocytopenic purpura; PAIgG, platelet-associated IgG; TES, $10 \mathrm{mM} \mathrm{N}$-Tris (hydroxymethyl)-2-amino-ethanesulfonic acid. 
quantitating PAIgG do not distinguish between antibody directed against a specific platelet antigen and IgG that is nonspecifically adsorbed onto the platelet surface. There are reports documenting the presence of a receptor for the Fc portion of IgG on the platelet surface which binds some subclasses of IgG without regard to their antigen specificity $(11,12)$. Binding of aggregated IgG or immune complexes to this receptor can be inhibited by normal plasma concentrations of monomeric IgG (13). Therefore, the physiologic significance of this receptor has not been established. We tested the hypothesis that true autoantibodies occur in some immune thrombocytopenias and identified platelet proteins containing the target antigens for these anti-platelet antibodies.

The target antigen implicated in posttransfusion purpura and in most cases of neonatal alloimmune thrombocytopenia is $\mathrm{PI}^{\mathbf{A 1}}$, which has been localized to glycoprotein IIIa (GPIIIa) $(14,15)$. However, the target antigens for antibodies in ITP patients are not well characterized. It has recently been reported that immunoglobulins from patients with ITP react with normal platelets but not with platelets from patients with Glanzmann's thrombasthenia (16). Thrombasthenic platelets are deficient in glycoproteins IIb and IIIa $(17,18)$, so either or both of these major membrane proteins could bear important target antigens for destructive antibodies. Human hybridoma monoclonal anti-platelet antibodies have been produced from the fusion of a plasma cell line with lymphocytes isolated from a patient with ITP (19), but their specific antigenic targets have not been identified. Woods et al. (21) have used a monoclonal antibody to isolate GPIIb/IIIa, and have shown that IgG from ITP splenic culture supernatants (20) and from plasma obtained from 5 of 56 patients with chronic ITP (21) bound to this protein complex. Two of these plasma samples were able to immunoprecipitate the GPIIb/IIla complex (21); however, it was not determined which of the two proteins was actually antigenic. We have now directly identified GPIIIa as the specific target antigen for autoantibodies in some cases of chronic ITP.

\section{Methods}

Reagent grade chemicals were supplied by Sigma Chemical Co., St. Louis, MO except as noted.

Platelets. Samples of $25 \mathrm{ml}$ of blood from normal $\mathrm{Pl}^{\mathrm{Al}}$ positive volunteers or $\mathrm{PI}^{\wedge 1}$ negative mothers of infants with neonatal alloimmune thrombocytopenia were collected in syringes that contained $5 \mathrm{ml}$ acid citrate dextrose with $10 \mathrm{mM}$ EDTA. Platelet-rich plasma was obtained by centrifugation at $230 \mathrm{~g}$ for $20 \mathrm{~min}$ at room temperature. Platelets were gel filtered over Sepharose 2B (Pharmacia, Uppsala, Sweden) (22), collected by centrifugation at $800 \mathrm{~g}$ for $20 \mathrm{~min}$ at room temperature, and washed three times in a modified $10 \mathrm{mM} \mathrm{N}$-Tris (hydroxymethyl)2-amino-ethanesulfonic acid (TES)-Tyrodes buffer containing $136 \mathrm{mM}$ $\mathrm{NaCl}$, TES (Calbiochem-Behring Corp., San Diego, CA), $2.6 \mathrm{mM}$ $\mathrm{KCl}, 0.5 \mathrm{mM} \mathrm{NaH} \mathrm{PO}_{4}, 2 \mathrm{mM}$ EDTA, $2 \mathrm{mM} \mathrm{MgCl}$, and $5.5 \mathrm{mM}$ glucose, $\mathrm{pH}$ 7.4. Contamination with white blood cells was $<1$ cell/ 1,000 platelets. For adsorption and elution studies, platelets were suspended in $1 \mathrm{mg} / \mathrm{ml}$ bovine serum albumin (BSA) in phosphatebuffered saline (PBS) with $2 \mathrm{mM}$ EDTA at a density of $2 \times 10^{9}$ platelets/ml. For SDS polyacrylamide gel electrophoresis (SDS-PAGE), platelets were suspended in TES-Tyrodes buffer at a density of 2 $\times 10^{9}$ platelets $/ \mathrm{ml}$ and solubilized by addition of an equal volume of $60 \mathrm{mM}$ Tris-HCl, pH 6.8, 10\% (wt/vol) SDS, with or without $1 \% 2$ mercaptoethanol and then boiled for $5 \mathrm{~min}$.

Glanzmann's thrombasthenia platelets. Platelets from a patient with Glanzmann's thrombasthenia were kindly supplied by Dr. Gilbert White, University of North Carolina, Chapel Hill, NC. The donor's platelets have been documented to have the complete absence of GPIIb/IIIa $(23,24)$, which defines type I Glanzmann's thrombasthenia $(17,18)$.

Fluorescence-activated cell sorter assay for PAIgG. PAIgG was assayed by a modification of the method of Verheught et al. (25). Platelet-rich supernatant obtained after 2\% Dextran T-500 (Pharmacia Fine Chemicals, Uppsala, Sweden) sedimentation at $1 \mathrm{~g}$ for $30 \mathrm{~min}$ was fixed by addition of formaldehyde to $1 \%$. Platelets were washed free of plasma and incubated with fluorescein-conjugated staphylococcal protein $A$ or $F\left(a^{\prime}\right)_{2}$ fragments of rabbit anti-human IgG or $C 3$. Using a size distribution to exclude red cells and leukocytes, fluorescence intensity and size distribution were analyzed on a fluorescence-activated cell sorter (model FACSII, Becton-Dickinson \& Co., Mountain View, CA).

Indirect anti-platelet antibodies. The ability of patient serum to opsonize normal platelets was assessed by the method of Handin and Stossel (26).

$\mathrm{Pl}^{\mathrm{Al}}$ typing. $\mathrm{Pl}^{\mathrm{A} 1}$ typing was done by the method of Aster and Enright (27) as follows. Platelets were labeled with ${ }^{51} \mathrm{Cr}$ by incubation of $10^{8}$ platelets with $100 \mu \mathrm{Ci}$ sodium $\left[{ }^{51} \mathrm{Cr}\right]$ chromate in $0.2 \mathrm{ml}$ PBS for $30 \mathrm{~min}$ at room temperature. $1.2 \times 10^{7}$ labeled platelets in fresh plasma were incubated with $0.05 \mathrm{ml}$ of anti-PI $\left.\right|^{\mathrm{Al}}$ antiserum, incubated for $2 \mathrm{~h}$ at $37^{\circ} \mathrm{C}$, and sedimented. ${ }^{51} \mathrm{Cr}$ release was determined by counting the radioactivity of the supernatant. The $\mathrm{P}^{\mathrm{Al}}$ specificity of the antiserum was assessed by comparison of results of typing platelets from a large number of individuals using defined anti-PIA antibody that was kindly supplied by Dr. Richard Aster, Blood Center of Southeastern Wisconsin, Milwaukee, WI.

Lactoperoxidase catalyzed ${ }^{125}$ I labeling of platelets. Platelets from $20 \mathrm{ml}$ of blood in acid citrate dextrose were washed twice in $10 \mathrm{mM}$ Tris- $\mathrm{HCl}, 0.15 \mathrm{M} \mathrm{NaCl}, 2 \mathrm{mM}$ EDTA, pH 7.8, and resuspended at a density of $1.5 \times 10^{9}$ platelets $/ \mathrm{ml}$. To each milliliter of platelet suspension, $250 \mu \mathrm{Ci}\left[{ }^{125} \mathrm{I}\right] \mathrm{NaI}(17 \mathrm{Ci} / \mathrm{mg}$, sp act; $1 \mathrm{mCi} / 20 \mu$ l, concentration) (New England Nuclear, Boston, MA) and $12.5 \mu \mathrm{g}$ of lactoperoxidase were added with stirring. At 1-min intervals, $10-\mu$ l aliquots of $1 \mathrm{mM} \mathrm{H}_{2} \mathrm{O}_{2}$ were added for $10 \mathrm{~min}$. The platelets were then washed three times and resuspended in $1 \mathrm{ml}$ of the Tris/EDTA buffer. Aliquots were frozen in liquid nitrogen and stored up to 1 mo. Specific activity obtained was $\sim 25 \mu \mathrm{Ci} / 10^{9}$ platelets.

Sera. Serum samples employed were obtained from normal volunteers, a $\mathrm{Pl}^{\mathrm{A} 1}$ negative patient with posttransfusion purpura, two $\mathrm{PI}^{\mathrm{Al}}$ negative mothers of infants with neonatal alloimmune thrombocytopenia, and patients with chronic ( $>1 \mathrm{yr})$ or acute ITP. In all patients, the clinical diagnosis of ITP was supported by positive direct or indirect antiplatelet antibodies or by a shortened chromium-labeled platelet survival. Samples were stored in aliquots at $-70^{\circ} \mathrm{C}$ for up to 24 mo. They were not routinely heat inactivated.

Iodination of antibodies. ${ }^{125} \mathrm{I}$-labeled antibodies were prepared by the chloramine $\mathrm{T}$ method (28) using $0.1 \mathrm{mg}$ of the commercial affinitypurified antibodies described below and $1.0 \mathrm{mCi}$ of $\mathrm{Na}^{125} \mathrm{I}$. Free ${ }^{125} \mathrm{I}^{-}$ was removed by extensive dialysis with PBS or by desalting over a column of Sephadex G-25 (Pharmacia Fine Chemicals, Uppsala, 
Sweden). The specific activities obtained were between $10^{8}$ and $10^{9}$ $\mathrm{cpm} / \mathrm{mg}$. The radioactivity was $>95 \%$ precipitable with trichloroacetic acid.

Separation of platelet proteins and transfer to nitrocellulose. SDSPAGE was performed by the method of Laemmli (29) using 3\% polyacrylamide stacking and either 6 or 7\% separating slab gels. Electrophoresis was performed at $15 \mathrm{~V}$ until a bromophenol blue tracking dye reached the bottom of the gel. The following molecular weight markers were utilized: myosin $(200,000), \beta$-galactosidase $(116,250)$, phosphorylase B $(92,500)$, BSA $(66,200)$, and ovalbumin $(45,000)$ (Electrophoresis grade reagents were obtained from Bio-rad Laboratories, Richmond, CA). The separated proteins were then electrophoretically transferred from the polyacrylamide gel to $0.45-\mu \mathrm{m}$ pore size nitrocellulose paper (Schleicher \& Schuell, Keene, NH) by the "Western blotting" technique (30) using an E-C "Electroblot" (E-C Apparatus Corp., St. Petersburg, FL) apparatus. Transfer was complete in $2 \mathrm{~h}$ at $5 \mathrm{~W}$ as assayed by staining the gel with Coomassie Brilliant Blue.

Immune staining. ${ }^{125}$ I antiglobulin technique. Remaining nonspecific protein binding sites on the nitrocellulose paper were blocked by incubation with $10 \%(\mathrm{wt} / \mathrm{vol}) \mathrm{BSA}$ and $0.5 \%$ bovine gamma globulin in PBS (BSA/BGG) for $1 \mathrm{~h}$ at $37^{\circ} \mathrm{C}$. The blot was then incubated for $1 \mathrm{~h}$ at $25^{\circ} \mathrm{C}$ with $25 \mu \mathrm{l}$ of the serum to be tested and diluted into 8 $\mathrm{ml}$ BSA/BGG. Unbound IgG was removed by washing 10 times with $50 \mathrm{ml}$ of cold PBS in a Petri dish with gentle agitation. Localization of bound immunoglobulin was accomplished by incubation with affinity purified ${ }^{125} \mathrm{I}$-labeled goat anti-human IgG (Litton Bionetics, Kensington, MD) for $1 \mathrm{~h}$ at $25^{\circ} \mathrm{C}$ or overnight at $4^{\circ} \mathrm{C}\left(10^{6} \mathrm{cpm} / \mathrm{ml}\right)$. After washing 10 times with $50 \mathrm{ml}$ PBS, the blot was exposed to X-Omat AR x-ray film (Eastman Kodak Co., Rochester, NY) for 4$24 \mathrm{~h}$ at $-70^{\circ} \mathrm{C}$.

Adsorption and ether elution of ITP antibodies from platelets. Platelets prepared as described above were incubated with test serum in a ratio of $0.3 \mathrm{ml}$ of platelet suspension $\left(10^{9} \mathrm{cells} / \mathrm{ml}\right.$ in $0.2 \%$ BSA, $2 \mathrm{mM}$ EDTA in PBS) to $0.3 \mathrm{ml}$ of serum and incubated at $37^{\circ} \mathrm{C}$ for $30 \mathrm{~min}$. The platelets were sedimented in a Beckman microfuge for 5 min, the supernatant was discarded, and the platelets were washed three times with $1 \mathrm{ml}$ of $0.2 \%$ BSA, $2 \mathrm{mM}$ EDTA in PBS, and resuspended in $0.3 \mathrm{ml}$ of the same buffer. The elution technique used is a modification of the method of von dem Borne (31). Diethyl ether was added to a total volume of $1.0 \mathrm{ml}$ and the suspension was vortexed vigorously for $2 \mathrm{~min}$ and then incubated for $30 \mathrm{~min}$ in closed tubes at $57^{\circ} \mathrm{C}$ in a hood. After centrifugation for $5 \mathrm{~min}$ in the microfuge, the upper layers of ether and stroma were aspirated, leaving the aqueous eluate. The eluate, $\sim 0.3 \mathrm{ml}$, was diluted to $8 \mathrm{ml}$ with BSA/BGG and used to stain the nitrocellulose transfers.

Immune staining-peroxidase technique. Nitrocellulose strips containing a single lane of platelet proteins were incubated first with $1.5 \%$ goat serum in PBS for $1 \mathrm{~h}$ to saturate protein binding sites and then with a 1:50 dilution of ITP serum in PBS with $1 \%$ BSA (PBS/1\% BSA) for $1 \mathrm{~h}$. The strips were washed 3-5 times for $5 \mathrm{~min}$ with $2.5 \mathrm{ml}$ of PBS/1\% BSA or PBS between subsequent incubation steps. A 1:200 dilution of biotinylated affinity purified goat anti-human IgG (Vector Laboratories, Burlingame, CA) in PBS/1\% BSA was added for 15 min. After exposure for $30 \mathrm{~min}$ to a $1 \%$ solution of avidin and biotinylated horseradish peroxidase (Vector Laboratories) in PBS containing $0.1 \%$ Tween 20 detergent, $25 \mathrm{ml}$ of $0.02 \%$ chloronaphthol and $0.006 \%$ hydrogen peroxide in PBS were added. Purple bands developed within $2 \mathrm{~min}$. All solutions were prepared fresh each day; azide was not added, since it inhibits the peroxidase reaction.

\section{Results}

Identification of the $P^{A 1}$ antigen-bearing protein. Our technique, detailed above, utilized a two step procedure which assessed antibody binding to platelet proteins which had been denatured with SDS, separated electrophoretically, and immobilized on nitrocellulose paper. During this latter process, renaturation of the proteins presumably occurred. When anti-PI ${ }^{\mathrm{Al}}$ serum (derived from a patient with posttransfusion purpura) was incubated with the separated and immobilized platelet proteins, radiolabeled anti-human IgG bound to a band of apparent molecular weight of 100,000 , which co-migrated with the major band from lactoperoxidase radioiodinated platelets (Fig. $1, A$ and $B)$. No antibody binding occurred when control serum was used (Fig. $1 C$ ) or when the target platelets were from a patient with Glanzmann's thrombasthenia (Fig. 1 D). This patient has a documented absence of glycoproteins IIb and IIIa $(23,24)$. Reduction of disulfide bonds in the normal platelet sample with $1.0 \% 2$-mercaptoethanol at $100^{\circ} \mathrm{C}$ for 5 min also completely eliminated antibody binding to the 100,000 -mol wt band. These findings were in accord with reports localizing the $\mathrm{PI}^{\mathrm{A} 1}$ antigen to glycoprotein $\mathrm{IIIa}(14,15)$, and established that the antigenicity of $\mathrm{Pl}^{\mathrm{A} 1}$ could survive the solubilization, separation, and transfer processes.

"Nonspecific" binding of immunoglobin to platelets. When the nonreduced, electrophoretically separated platelet proteins were incubated with either control or anti-P ${ }^{\mathrm{Al}}$ serum, additional bound immunoglobulin was identified at 200,000 mol wt (Fig. $1, A, C$, and $D$ ). This band was also observed if the serum incubation was omitted and the platelet proteins were incubated directly with ${ }^{125}$ I goat anti-human IgG (Fig. 2, $A$ and $B$ ). The intensity of this band was increased if the serum had been heated to $60^{\circ} \mathrm{C}$ unless protein aggregates were subsequently removed by ultracentrifugation. A faint IgG band noted at

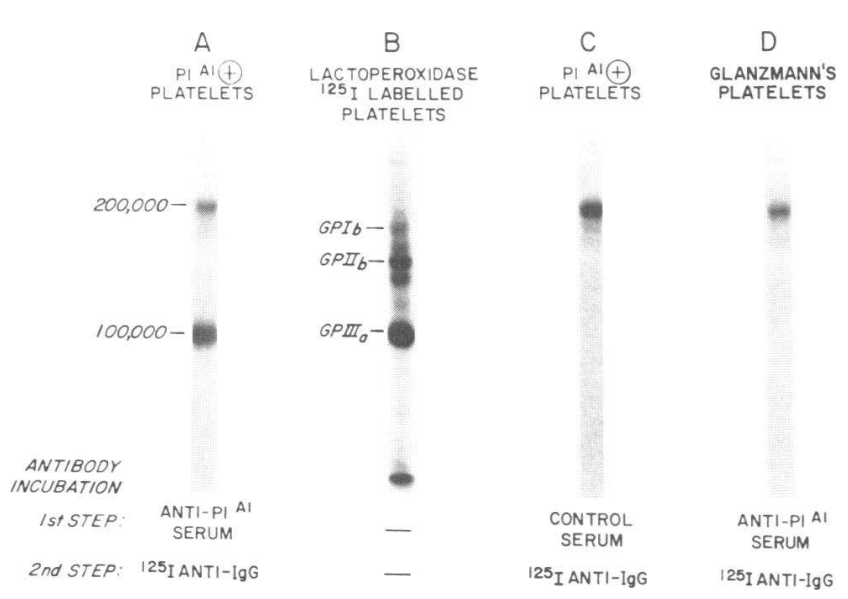

Figure 1. $\mathrm{Pl}^{\mathrm{Al}}$. Autoradiograms of platelet protein preparations separated by SDS-PAGE, transferred to nitrocellulose, and subjected to antibody incubations as indicated at the bottom of the figure. Note the 100,000 -mol wt band which co-migrates with GPIIIa. 
$\sim 150,000$ mol wt could be accentuated by overexposure of the autoradiograms. The intensity of this band varied with different platelet preparations. It was very strong if the platelets were not gel filtered. When platelet proteins were reduced with 2-mercaptoethanol, the 200,000-mol wt band disappeared and bands appeared at molecular weights of 50,000 and 25,000 (Fig. $2 C$ ). However, if the separated, reduced platelet proteins were first incubated with heat-aggregated serum, additional IgG bound to a 45,000-mol wt band (Fig. $2 \mathrm{D}$ ). Furthermore, exposure of the electrophoretically separated platelet proteins to heat aggregated ${ }^{125} \mathrm{I}$-labeled human IgG resulted in direct binding of radioactivity to the 200,000 -mol wt band of the nonreduced platelet proteins and to the 45,000 -mol wt band of reduced proteins (results not shown).

Binding of ITP antibodies to platelet membrane proteins. Although sera from patients with ITP appear to contain opsonic activity against platelets, indirect antibody tests are frequently negative (2). To concentrate the anti-platelet immunoglobulins, these sera were initially incubated with normal platelets. After washing to remove plasma proteins, plateletbound antibody was eluted with ether as detailed in Methods. Because this treatment is harsh, we found that recovery of antibody activity was unpredictable. Therefore, we developed and used the more sensitive peroxidase technique for antigen identification, which is detailed in Methods.

Sera from 13 patients with chronic ITP (see Table I) were studied using the adsorption and elution technique. In nine cases, a specific band was found at $100,000 \mathrm{~mol} \mathrm{wt}$, comigrating with glycoprotein IIIa (e.g., Fig. $3 \mathrm{~B}$ ). In the four other patients with chronic ITP, only the nonspecific 200,000 mol wt band was seen. When target platelet proteins from a patient with type I Glanzmann's thrombasthenia were used to test three of these sera, no antibody bound to the 100,000 mol wt protein (Fig. $3 \mathrm{D}$ ), which confirmed its identification

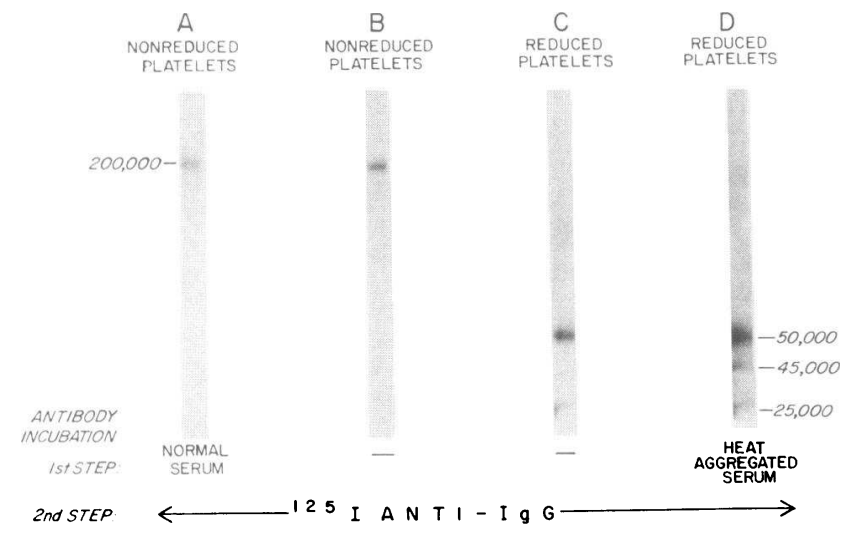

Figure 2. Nonspecific PAIgG. Autoradiograms of nitrocellulose transfers of platelet proteins subjected to human serum and antibody incubations as indicated. Note the $200,000 \mathrm{~mol}$ wt nonspecific band of nonreduced preparations and the $45,000-\mathrm{mol}$ wt band of reduced platelet proteins. as glycoprotein IIIa. When disulfide bonds were reduced in the target control platelet proteins, the antigenic band was noted at $110,000 \mathrm{~mol} \mathrm{wt}$. This increase in apparent molecular weight with disulfide reduction is characteristic of GPIIIa (32). In order to test whether the antiplatelet antibodies in ITP sera were directed against the $\mathrm{Pl}^{\mathrm{A} 1}$ antigen, three of these ITP sera were tested against $\mathrm{Pl}^{\mathrm{A} 1}$ negative platelets. The $100,000-\mathrm{mol}$ wt band was still observed (e.g., Fig. $3 E$ ). We also studied sera from eight children with acute ITP of childhood. AntiGPIIIa antibodies were not demonstrated in any of these patients.

Detection of platelet-directed antibody in the serum of a patient with ITP does not assure that it is an autoantibody. Patients who have been transfused or pregnant may have platelet specific alloantibodies or isoantibodies. Six of our nine patients with specific platelet directed IgG had been transfused; none had been pregnant. We directly demonstrated in two cases that the anti-GPIIIa IgG was truly an autoantibody. In one case, IgG eluted from patient platelets was shown to bind to the $100,000-\mathrm{mol} w \mathrm{wt}$ band of control platelets. In another case, the patient's own platelet proteins were used as the target for immune staining. IgG in the same patient's serum bound to the $100,000-$ mol wt band (results not shown).

\section{Discussion}

While increased platelet bound IgG has a well documented association with immune thrombocytopenias, the precise mechanism for platelet opsonization and destruction has not been elucidated. We report here the direct demonstration of anti-platelet autoantibodies in a subset of patients with chronic ITP. Since we have been able to differentiate antiplatelet IgG from nonspecific platelet-associated IgG, we were also able to identify the platelet protein bearing target antigens in immune thrombocytopenias.

Platelet glycoprotein IIIa was shown to contain the $\mathrm{Pl}^{\mathrm{Al}}$ antigen, confirming previous reports $(14,15)$. Using anti-PlA1 posttransfusion purpura serum, antibody binding was demonstrated to an antigenic protein with an apparent molecular weight of 100,000 , which disappeared after reduction with 2mercaptoethanol.

Indirect antibody testing has been of limited clinical usefulness in ITP, since the frequency of positive results is low (2) and the levels do not correlate with the clinical course (33). Previously reported direct assays of platelet-associated IgG (5-8) do not differentiate specific antiplatelet antibody binding from nonspecifically bound PAIgG. Furthermore, recent studies suggest that the abnormally increased amounts of PAIgG seen in ITP may not represent platelet antigen-directed antibodies $(9,10)$.

We were able to separate the specific and nonspecific components of immunoglobulin binding to platelets. In ITP, we identified a group of patients having serum anti-platelet IgG which binds specifically to glycoprotein IIIa. This IgG was 
Table I. Clinical Features of Patients with Chronic ITP

\begin{tabular}{|c|c|c|c|c|c|c|c|c|}
\hline Patient & Age & $\operatorname{Sex}(M / F)$ & Pregnancies? & Transfusions? & Splenectomy? & Response & $\begin{array}{l}\text { Antiplatelet } \\
\text { antibodies- } \\
\text { direct/indirect }\end{array}$ & $\begin{array}{l}100,000-\mathrm{mol} \text { wt } \\
\text { antigen band }\end{array}$ \\
\hline & $y r$ & & & & & & & \\
\hline 1 & 15 & $\mathbf{M}$ & - & Platelets & Yes & No & $-1+$ & + \\
\hline 2 & 5 & $\mathbf{F}$ & no & No & No & - & $+1+$ & + \\
\hline 3 & 11 & $\mathbf{F}$ & no & No & Yes & Yes & $+1-$ & + \\
\hline 4 & 18 & $\mathbf{F}$ & no & No & No & - & $-1+$ & - \\
\hline 5 & 19 & $\mathbf{M}$ & - & No & Yes & No & $+/+$ & - \\
\hline 6 & 15 & $\mathbf{F}$ & no & Platelets & No & - & $+1+$ & + \\
\hline 7 & 16 & $\mathbf{M}$ & - & RBC's, platelets & No & - & $+1-$ & + \\
\hline 8 & 13 & $\mathrm{~F}$ & no & No & No & - & $+1-$ & - \\
\hline 9 & 12 & $\mathbf{M}$ & - & Platelets & No & - & $+1-$ & - \\
\hline 10 & 13 & $\mathbf{F}$ & no & Platelets & Yes & Yes & $+/-$ & + \\
\hline 11 & 19 & $\mathbf{M}$ & - & Platelet survival study & No & - & $-1-$ & + \\
\hline 12 & 4 & $\mathbf{F}$ & no & RBC's, platelets & Yes & No & $+1+$ & + \\
\hline 13 & 13 & $\mathbf{F}$ & no & Platelet survival study & No & - & $+1-$ & + \\
\hline
\end{tabular}

RBC's, red blood cells.

shown to be an autoantibody, rather than an alloantibody. In one case, IgG eluted from the patient's own platelets was shown to bind to GPIIIa from control platelets; in another case, patient platelets were electrophoresed and IgG in patient serum was shown to bind to the patient's own GPIIIa. Despite its localization on glycoprotein IIIa, the target antigen is different from $\mathrm{Pl}^{\mathrm{A}}$, since the eluted sera can bind to $\mathrm{Pl}^{\mathrm{Al}}$

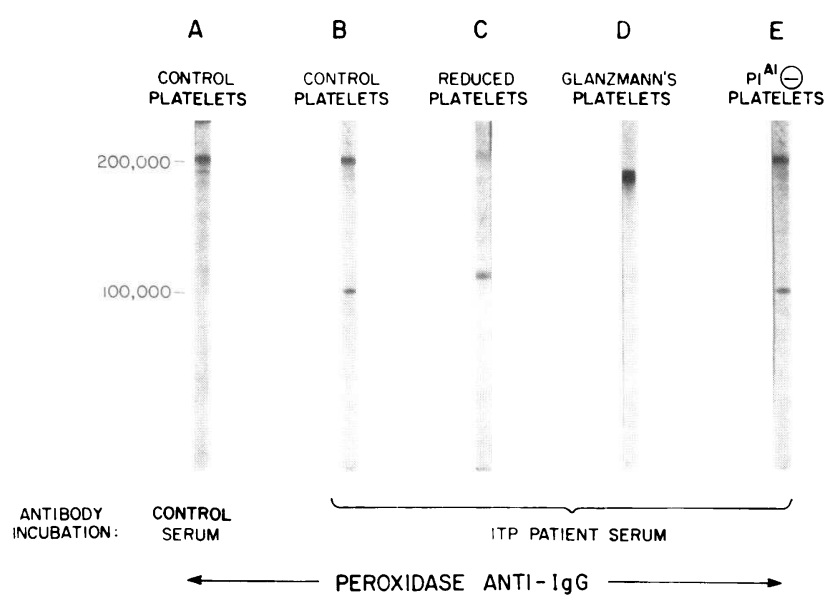

Figure 3. Chronic ITP. Photographs of nitrocellulose transfers of platelet proteins incubated with ITP serum or control serum as indicated, followed by biotinylated goat anti-human IgG, avidin, and biotinylated horseradish peroxidase. Colored bands appeared after addition of chloronaphthol. Note the specific 100,000 -mol wt protein which binds IgG. This protein is absent in Glanzmann's thrombasthenic platelets and is converted to an apparent molecular weight of 110,000 upon reduction of disulfides. negative as well as positive platelets. Apparently, glycoprotein IIIa bears a number of important target platelet antigens and may be analogous to the erythrocyte glycoprotein, glycophorin, which contains a number of important red cell antigens (34). These studies allow a direct identification of the target antigen in ITP. Furthermore, our findings suggest that it may be possible to identify a subset of patients with ITP who have a true autoantibody.

We were unable to identify a specific anti-platelet antibody in sera from all patients with chronic ITP. There are a number of possible explanations. First, in some patients the antiplatelet antibody may have been present in too low a titer to permit identification even using the adsorption and elution technique. We were not able to quantitate the anti-platelet activity of these sera, but we did find antibodies to glycoprotein IIIa to be intermittently positive and negative in three patients who were followed over a year. Also, IgM antibodies would not be identified with our anti-IgG second antibody. An alternative explanation for a negative result would be an antiplatelet antibody that was directed against an epitope not present on the test platelets, or one that lost its antigenicity in the solubilization and separation process. Finally, in some patients there may be a different pathogenic mechanism for thrombocytopenia than autoantibodies, such as immune complex deposition leading to platelet destruction. No conclusions can be drawn regarding the frequency of autoantibodies in ITP from these studies, since the patients were not randomly selected.

Our preparations of SDS-PAGE separated platelet proteins contained small amounts of human IgG (MW 150,000). The intensity of this band varied with different platelet preparations. It was very strong if the platelets were not gel filtered. 
When disulfide bonds were reduced with 2-mercaptoethanol, this IgG appeared as two bands of 50,000 and $25,000 \mathrm{~mol} \mathrm{wt}$, which were compatible with the heavy and light chains of IgG. Exposure of the separated nonreduced proteins to heat aggregated IgG followed by ${ }^{125} \mathrm{I}$ goat antihuman $\mathrm{IgG}$ resulted in binding to a $200,000-\mathrm{mol}$ wt band. Binding to a 45,000-mol wt band was observed when reduced platelet proteins were used. If the aggregated IgG was removed by ultracentrifugation, the band decreased in intensity. Furthermore, the same bands were visualized after direct exposure to ${ }^{125} \mathrm{I}$ human IgG or to the ${ }^{125}$ I goat antihuman IgG alone. One explanation for these findings is that an IgG receptor of apparent molecular weight of 200,000 when nonreduced and 45,000 when reduced has little species specificity, and can bind the goat antibody directly as well as human IgG. Alternatively, the 200,000 -mol wt band could contain human IgG $(150,000 \mathrm{~mol} \mathrm{wt})$ complexed to the receptor $(45,000 \mathrm{~mol} w \mathrm{wt})$ that is not released until disulfide bonds are reduced. A platelet glycoprotein with Fc receptor properties has been reported to have similar molecular weights (255,000 nonreduced; 50,000 reduced) (12). The precise nature of the receptor we observe is currently under investigation.

In summary, we have identified antibody binding to platelet antigens on a 100,000-mol wt protein, GPIIIa, and we have separated this specific anti-platelet IgG binding from nonspecific immunoglobulin associated with normal platelets. The antiplatelet antibodies we observed in a subset of patients with chronic ITP also bound to GPIIIa. These anti-GPIIIa antibodies were not found in any of the acute ITP patients that were studied. If future prospective studies confirm this finding, demonstration of autoantibody could be used to identify a subset of patients who are destined to have chronic ITP at the time of presentation, and therefore improve decisions regarding patient management.

\section{Acknowledgments}

Platelets from a patient with Glanzmann's thrombasthenia were kindly supplied by Dr. Gil White, University of North Carolina, Chapel Hill, NC. Anti-PI ${ }^{\wedge 1}$ antiserum was a gift from Dr. Richard Aster, Blood Center of Southeastern Wisconsin, Milwaukee, WI. Mrs. Heidi Taatjes provided outstanding technical assistance. The authors thank Mrs. Jeanne Glennon for excellent secretarial assistance.

This work was supported by National Heart, Lung, and Blood Institute grants HL-17513, RCDA-K04HL00236 (to Dr. Handin), and 5PO1-HL27375 (to Dr. Lux), by a National Institute of Arthritis, Diabetes, Digestive, and Kidney Diseases grant 2RO1-AM21836 (to Dr. Lux), and by a William Randolph Hearst Fund grant (to Dr. Beardsley).

\section{References}

1. McMillan, R. 1981. Chronic idiopathic thrombocytopenic purpura. N. Engl. J. Med. 304:1135-1147.

2. Kelton, J. G., and S. Gibbons. 1982. Autoimmune Thrombocytopenia. Sem. Thrombosis and Hemost. 8:83-104.
3. Klein, C. A., and M. A. Blajchman. 1982. Alloantibodies and Platelet Destruction. Sem. Thromb. Hemostasis. 8:105-115.

4. Harrington, W. J., V. Minnich, J. W. Hollingsworth, and C. V. Moore. 1951. Demonstration of a thrombocytopenic factor in the blood of patients with thrombocytopenic purpura. J. Lab. Clin. Med. 38:1-10.

5. Cines, D. B., and A. D. Schreiber. 1979. Immune thrombocytopenia: use of a Coombs antiglobulin test to detect $\mathrm{IgG}$ and $\mathrm{C}_{3}$ on platelets. N. Engl. J. Med. 300:106-111.

6. Leporrier, M., G. Dighiero, M. Auzemery, and J. L. Binet. 1979. Detection and quantification of platelet bound antibodies with immunoperoxidase. Br. J. Haematol. 42:605-611.

7. Luiken, G. A., R. McMillan, A. L. Lightsey, P. Gordon, S. Zeverly, I. Schulman, J. T. Gribble, and R. L. Longmire. 1977. Platelet-associated IgG in immune thrombocytopenic purpura. Blood. 50:317-325.

8. McMillan, R. T., R. S. Smith, R. L. Longmire, R. Yelenosky, R. T. Reid, and C. G. Carddock. 1971. Immunoglobulins associated with human platelets. Blood. 37:316-322.

9. Shulman, N. R., C. A. Leissinger, A. Hotchkiss, and C. Kautz. 1980. An in vitro model demonstrating that elevated platelet-associated IgG is a non-specific consequence of platelet destruction. Blood. 60(Suppl. 1):191a.

10. Kelton, J. G., and K. Steeves. 1982. The amount of plateletbound albumin parallels the amount of IgG on washed platelets from patients with immune thrombocytopenia. Blood. 60(Suppl. 1):188a.

11. Henson, P. M. 1969. The adherence of leukocytes and platelets induced by fixed IgG antibody or complement. Immunology. 16:107121.

12. Cheng, C. M., and J. Hawiger. 1979. Affinity isolation and characterization of immunoglobulin $\mathrm{G} \mathrm{Fc}$ fragment-binding glycoprotein from human blood platelets. J. Biol. Chem. 254:2165-2167.

13. Pfeuller, S. L., S. Weber, and E. F. Luscher. 1977. Studies of the mechanism of the human platelet release reaction induced by immunologic stimuli. J. Immunol. 118:514-524.

14. Kunicki, T. J., and R. H. Aster. 1979. Isolation and immunologic characterization of the human platelet alloantigen $\mathrm{Pl}^{\wedge 1}$. Mol. Immunol. 16:353-360.

15. McMillan, R., D. Mason, P. Tani, and G. M. Schmidt. 1982. Evaluation of platelet surface antigens: localization of the $\mathrm{Pl}^{\mathrm{Al}}$ alloantigen. Br. J. Haematol. 51:297-304.

16. van Leeuwen, E. F., J. T. M. van der Ven, C. P. Engelfriet, and A. E. G. K. von dem Borne. Specificity of autoantibodies in antiimmune thrombocytopenia. Blood. 59:23-26.

17. Nurden, A. T., and J. P. Caen. 1974. An abnormal platelet glycoprotein pattern in three cases of Glanzmann's thrombasthenia. Br. J. Haematol. 28:253-260.

18. Phillips, D. R., and P. Poh Agin. 1977. Platelet membrane defects in Glanzmann's thrombasthenia. Evidence for decreased amounts of two major glycoproteins. J. Clin. Invest. 60:535-545.

19. Hsu-Lin, S. C., Y. Shoenfeld, B. Furie, and R. S. Schwartz. 1982. Human hybridoma-produced monoclonal antibodies that bind to platelets. Blood. 60(Suppl. 1):187a.

20. McMillan, R., and V. L. Woods. 1983. Antibodies and antigens in chronic immune thrombocytopenic purpura (ITP). Thromb. Hemostasis. 50:330.

21. Woods, V. L., E. H. Oh, D. Manson, and R. McMillan. 1984. Autoantibodies against the platelet glycoprotein IIb/IIIa complex in patients with chronic ITP. Blood. 63:368-375. 
22. Tangen, O., H. J. Berman, and P. Marfey. 1971. Gel filtration: a new technique for separation of blood platelets from plasma. Thromb. Diath. Haemorrh. 25:268-278.

23. White, G. C. II, E. F. Wrokman, Jr., and R. L. Lundblad. 1978. Thrombin binding to thrombasthenic platelets. J. Lab. Clin. Med. 91:76.

24. Holahan, J. R., and G. C. White II. 1981. Heterogeneity of membrane surface proteins in Glanzmann's thrombasthenia. Blood 57:174.

25. Verheught, F. W. A., A. E. G. K. von dem Borne, J. C. van Noord-Bokhorst, and C. P. Engelfriet. 1978. Autoimmune granulocytopenia: the detection of granulocytes autoantibodies with the immunofluorescence test. Br. J. Haematol. 39:339-350.

26. Handin, R., and T. Stossel. 1974. Phagocytosis of antibodycoated platelets by human granulocytes. N. Engl. J. Med. 290:989993.

27. Aster, R. H., and S. E. Enright. 1969. A platelet and granulocyte membrane defect in paroxysmal nocturnal hemoglobinuria. Usefulness for the detection of platelet antibodies. J. Clin. Invest. 48:1199.

28. Hunter, M. W., and F. C. Greenwood. 1962. Preparation of iodine labelled human growth hormone of high specific activity. Nature (Lond.). 194:495-496.
29. Laemmli, V. K. 1970. Cleavage of structural proteins during the assembly of the head of bacteriophage T4. Nature (Lond.). 227:685.

30. Towbin, H., T. Staehelin, and J. Gordon. 1979. Electrophoretic transfer of proteins from polyacrylamide gels to nitrocellulose sheets: procedure and some applications. Proc. Natl. Acad. Sci. USA. 76:43504354.

31. von dem Borne, A. E. G. K., F. M. Helmerhorst, E. F. van Leeuwen, H. G. Pegels, E. von Riesz, and C. P. Engelfriet. 1980. Auto immune thrombocytopenia: detection of platelet autoantibodies with the suspension immunofluorescence test. Br. J. Haematol. 45:319327.

32. Phillips, D. R., and P. Poh Agin. 1977. Platelet membrane glycoproteins: evidence for the presence of nonequivalent disulfide bonds using nonreduced-reduced two-dimensional gel electrophoresis. J. Biol. Chem. 252:2121-2126.

33. Dixon, R., W. Rosse, and L. Erbert. Quantitative determination of antibody in idiopathic thrombocytopenic purpura: correlation of serum and platelet-bound antibody with clinical response. $N$. Engl. J. Med. 292:230-236.

34. Marchesi, V. T., H. Furthmayr, and M. Tomita. 1976. The red cell membrane. Annu. Rev. Biochem. 45:667-698. 